\title{
An unusual minor protein appearing in embryonic axis cells of haricot bean seeds following germination process stimulated by 6-methylthiouracil
}

\author{
Victoria A. Tsygankova, Vladimir N. Zayetz, Larisa A. Galkina ${ }^{1}$, \\ Ludmila P. Prikazchikova', Yaroslav B. Blume \\ Institute of Cell Biology and Genetic Engineering, National Academy of Sciences of Ukraine \\ Acad. Zabolotny str., 148, Kyiv, $252 ! 43$ \\ Murmanska str., i, Kyiv, 252600
}

\begin{abstract}
Using the two-dimensional polyacrylamide gel electrophoresis approach, an urusual $\approx 30$ kDa protein was found in embryonic axis cells of haricot bean seeds following seed germination process stimulated by 6-methylthiouracil. No similar protein was found both in control and lutidine N-oxide stimulated steds. The synthesis of an additional low molecular weight protein was also detected in a cell-free system prepared from rabbit reticulocytes in the presence of poly $\left(\mathrm{A}^{+} \mathrm{RNA}\right.$ isolated from 6-methylthiouracil stimulated embryonic axes of haricot been seeds. At the same time the lutidine $N$-oxide was found to stimulate drastically the total polypeptide synthesis in an in vitro system prepared from wheat embryo in the presence of a "standard" poly $(A)^{+} R N A$ preparation, no similar effect of the 6 -methylthiouracil having been seen. The ratio of informosomes, free and incorporated into polyribosomes, was investigated following RNP-particles fractionation in a preformed $\mathrm{CsCl}$ gradient; the 6-methylthiouracil seed stimulation was shown to induce the development of an additional peak of synthetically active informosomes, their buoyant density being $1.46 \mathrm{~g} / \mathrm{cm}^{3}$. The 6-methylthiouracil stimulated seed germination causes a significant shortening of haricot plant ontogenesis period without any harmful changes of plant phenotype, the lutidine $N$-oxide stimulation leads, however, to deformed accelerated vegetative organ appearance accompanied by no repraductive organ development. Nature of $30 \mathrm{kDa}$ protein as well as some problems concerning the correlation between different stimulator-induced cellular gene expression changes taking place during early postembryogenesis and further processes of haricot bean plant growth and development are discussed; somte possible practical consequences of our experiments are also mentioned.
\end{abstract}

Introduction. Due to vast biological screening we have earlier shown [1] such substances as lutidine $\mathrm{N}$-oxide (LNO, ivin-yan) and 6-methylthiouracil (methyur, 6-MTU) accelerate sharply haricot bean seed germination. Our conviction is an embryonic axis of haricot bean plant (morpho-physiological and biochemical characteristics of embryonic axis set, formation and germination, its growth as well as development during embryogenesis and carly postembryogenesis, i. e. during haricot bean seeds maturation and germination were studied in detail $[2-4 \mid$ ) (C) V. A TSYGANKOVA, V. N. ZAYETZ, L. A. GALKINA. f. P. PRIKAZCHIKOVA, Y. B. BILIMF, I998 to be a suitable model permitting to investigate several actual problems of plant physiology and biotechnology, namely:

(i) to answer some questions concerning the mechanism of plant growth stimulator effect (these compounds are strongly different from naiural plant hormones in their chemical structure), to understand if synthetic stimulators act through the cellular receptor systems similarly to plant hormones or interact directly with some target molecules on the level of cellular regulatory system (i. e. at the level of genetic control or phytohormonal regulation of plant growth and morphogenesis);

(ii) to understand if the artificially stimulated 
plant growth causes any harmful changes affecting the sequence of normal morphogenetical events during the early postembryogenesis (mature fully differentiated organs from primary non-differentiated cmbryonic axis organs - root, hypocotyl and leaf, beginning to form in this period) and if any drastic growth stimulation realized during the first developmental stages is able to impair the balanced growth and development of plant vegetative and reproductive organs during further plant ontogenesis stages (for example, acceleration of vegetative organ growth and inhibition set as well as formation of plant reproductive organs).

To solve such problems as fully as possible we decided to get at first wo principal goals:

(i) to understand the mechanisms concerning the effect of two synthetic growth stimulators - 6-MTU and LNO changing cellular gene expression in embryonic axis cells at carly postembryogencsis stage and programming plant growth and development;

(ii) to study the consequences of artificial haricot seed germination on following plant vegetation.

Materials and Methods. Seeds. In our experiments seeds of haricol beans (Phaseolus vulgaris L.) of the variety «Bielozernaya» were used. Ethanolsterilized seeds were put for germination in a thermostat at $26{ }^{\circ} \mathrm{C}$; they were incubated between layers of filter paper moistened by distilled water or by $2 \%$ solutions containing plant growth regulators. After the seed incubation, embryonic axes were separated from cotyledons, washed by distilled water and divided into three parts (each containing 100 axes) aimed for isolation of proteins, RNA, and RNP-particles.

Protein extraction. The tissue samples of embryonic axes were frozen in liquid nitrogen and powdered carefully in a china mortar. 10 volumes of preliminary cooled to $0^{\circ} \mathrm{C}$ extracting buffer consisting of $30 \mathrm{mM}$ tris $\mathrm{HCl}, \mathrm{pH} 8.7,1 \mathrm{mM}$ dithiothreitol (DT'T), $1 \mathrm{mM}$ cthylentiaminetetraacetic acid (disodium salt), $1 \mathrm{mM}$ ascorbic acid, $5 \mathrm{mM} \mathrm{MgCl}_{2}$, and $10 \mathrm{mg}$ polyvinylpyrolidone were added to the triturated material. The extract obtained was twice run (during $10 \mathrm{~min}$ and $15 \mathrm{~min}$ ) in a centrifuge at $35.000 \mathrm{~g}$. The $3 / 4 \vee$ acidified acetone ( $\mathrm{pH} 4.5$ ), containing $0.07 \%$ 2-mercaptoethanol was added to supernatant fluid. This mixture was strongly shaken and incubated at $-20^{\circ} \mathrm{C}$ during $1 \mathrm{~h}$. The denatured proteins were then pelleted by centrifugation at $35.000 \mathrm{~g}$ during $10 \mathrm{~min}$. The pellets obtained werc dried using a vacuum evaporator and dissolved in a buffer containing $(50 \mu)$ per $1 \mathrm{mg}$ of dry precipitate): $8 \mathrm{M}$ urea, $5 \mathrm{mM} \mathrm{K} \mathrm{CO}_{3}, 0.5 \%$ DTT, $2 \%$ amphollynes solution - carricr ampholytes, their $\mathrm{pH}$ range being 3.5-9.5, $2 \%$ Triton X-100 (MKSD- buffer). The soluble protein extract was separated from insoluble material by probes centrifugation ( 3 min at $15.000 \mathrm{~g}$ ) and then kept at $-20^{\circ} \mathrm{C}$ until use.

Two-dimensional gel electrophoresis of proteins was realized according to the method described by O'Farrell [5] with several modifications. The protein fractionation in the first direction was made in a $5 \%$ polyacrylamide laminar gel $(\mathrm{C}=4 \% \mathrm{w} / \mathrm{w})$. The gel was polymerized in a $8 \mathrm{M}$ urea solution supplemented by $2 \%$ Triton $\mathrm{X}-100$ and $2 \%$ ampholines mixture (containing pharmalytes with $\mathrm{pH}$ ranges $3.5-9.5$ and $5.0-7.0$, their ratio being $3: 1)$ to stabilize the central $\mathrm{pH}$ gradient zone. The gel was $1 \mathrm{~mm}$ wide, its size being $140 \times 80 \mathrm{~mm}$. $0.02 \mathrm{M} \mathrm{NaOH}$ was used as a cathode electrode solution, and $0,01 \mathrm{M} \mathrm{H}_{3} \mathrm{PO}_{4}$ was taken as an anode one. The gel pre-focusing was made at $400 \mathrm{~V}$ during $30 \mathrm{~min}$. The protein electrophoresis was realized during $2 \mathrm{~h}$ at $1200 \mathrm{~V}$ in a cooled chamber. A gel strip with marker proteins was cut out and stained for marking gel lanes, all other ones containing protein fractions were polymerized in a polyacrylamide gel with a $5-15 \%$ concentration gradient to fractionate the proteins in the second direction realized in a buffer system described by Laemmli [6]. This gel was $1.5 \mathrm{~mm}$ wide, its size bcing $145 \times 145 \mathrm{~mm}$. As an electrode buffer a tris-glycine solution ( $\mathrm{pH} 8.3$ ) supplemented with SDS was used. The proteins entered to the concentrating gel at $70 \mathrm{~V}$ during $1 \mathbf{h}$, the protein fractionation in a separating gel was run during $6 \mathrm{~h}$ at $160 \mathrm{~V}$. Following separation the gel strips containing protein fractions were fixed by a mixture containing $30 \%$ isopropanol and $20 \%$ acetic acid and stained by a Coomassie brilliant bluc solution. The stain excess was washed out by a mixture containing $5 \%$ methanol and $7 \%$ acetic acid. The gels stained were then photographed on a glass plate lit from the opposite side.

The isolation of total RNA preparations was realized after embryonic axis tissue destruction using a buffer solution (buffer I) containing $0.05 \mathrm{M}$ tris$\mathrm{HCl}, \mathrm{pH} 7.6,0.01 \mathrm{M} \mathrm{MgCl}_{2}, 0.06 \mathrm{M} \mathrm{KCl}, 1 \% \mathrm{SDS}$, and $4 \mathrm{M}$ guanidine isothiocyanate. The lysate obtained was twice treated by a mixture of hot watersaturated phenol and chloroform; the RNA was precipitated from a water phase by ethanol, treated by proteinase $K$, deproteinized again by the samc phenol-chloroform mixture and precipitated by ethanol. Some polysaccharide contaminants present in RNA preparations (preventing fractionation molecular RNA and manifestation biological activity mRNA in vitro) were extracted by methoxyethanol; the RNA molecules were then precipitated by cetylthrimethylammonium bromide; this last reagent was eliminated by multiple re-dissolving of RNA preparations in a 
$0.01 \mathrm{M}$ sodium acetate solution followed by sodium acetate saturated ethanol precipitation.

Poly $(A)^{\prime \prime}$ RNA separation from poly $(A)$ RNA molecules was made using total RNA chromatography on the oligo(dT)-cellulose columns [7]. Total RNA preparations were analysed using electrophoresis in a $1.5 \%$ agarose gel containing $7 \mathrm{M}$ urea according 10 Locker [8]; the gels obtained had been saturated by ethidium bromide solution beforc RNA fractions photographing using an UV lamp. The poly (A) ${ }^{+}$RNA was analysed using a Northern-blot approach [9]. cDNA was synthesized on poly $(A)^{+}$RNA template according to the protocol described by Buell et al. $\{10 \mid$ using reverse transcriptase (revertase) and $\left[\alpha-{ }^{32} \mathrm{P}\right]-$ containing deoxy-CTP as a label. A poly (A) ${ }^{+}$RNA preparation was fractionated by electrophoresis in an agarose gel in the presence of formalyn; electrophoretically pure poly (A) ${ }^{+}$RA fractions were transferred on nitrocellulose filters and hybridized with cDNA. The hybridization mixture contained $50 \%$ formamide, $5 X$ Upper buffer $(\mathrm{pH} \mathrm{7.0)}, 5 \mathrm{X}$ Denhardt's solution $111 \mathrm{l}$, denatured calf thymus DNA $(100 \mu \mathrm{g} / \mathrm{ml})$, poly (A) ${ }^{+}$RNA $(1 \mu \mathrm{g} / \mathrm{ml}), 0.1 \%$ SDS, and $\left[a-{ }^{32} \mathrm{P}\right]-\mathrm{cDNA}\left(1.5 \cdot 10^{8} \mathrm{cpm}\right)$. Following hybridization, filters were carefully washed from exogenous label and exposed during $24 \mathrm{~h}$ to a film PM-1 with an accelerating screen (at $-70^{\circ} \mathrm{C}$ ). The limits of poly (A) ${ }^{+}$RNA sizes were evaluated according to radioautograph distribution of labelled poly $(\mathrm{A})^{+} \mathrm{RNA}-\mathrm{cDNA}$ hybrids along the gel lanes (with regard to marker polynuclcotides).

The experiments with poly(A) RNA translation were carried out in cell-free systens derived from wheat embryos 112) for quantitative determination incorporation of radioactive label into polypeptide material and rabbit reticulocytes [9] for definition fractional composition of full-length new synthesizing polypeptides, using $\Gamma^{35} \mathrm{~S} \mid-$ methionine as a labelling compound. The polypeptides synthesized de novo in this last in vitro system were analyzed using the one-dimensional PAGE approach as mentioned above. The gels obtained were dried using a heating vacuumdryer ( $\ll L K B »$, Sweder $)$. The gel fluorography was made using a protocol described in [13], the gels having been saturated by a fluorescent reagent, 2,5-diphenyloxazole (PPO) [14].

Radioactive labelling of $R N P$-particles. The embryonic axis samples (100 axes) were thoroughly washed by distilled water and incubated in a $\left[{ }^{3} \mathrm{H}\right]$ uridine solution $\left(3.7 \cdot 10^{6} \mathrm{~Bq} / \mathrm{ml}\right)$ containing also penicillin and streptomycin $(50 \mu \mathrm{g} / \mathrm{ml})$ to prevent the label incorporation by contaminating bacterial cells present in incubation mixture. The material was incubated during $1 \mathrm{~h}$ in a thermostat at $28{ }^{\circ} \mathrm{C}$ in a
Petri dish and then washed by distilled water to remove all the non-incorporated label.

I solation of labelled cytoplasmic RNP-particles. A sample of embryonic axis tissue was homogenized in the buffer II (containing $20 \mathrm{mM}$ TEA-HCl, pH 7.6, $25 \mathrm{mM} \mathrm{KCl}, 3 \mathrm{mM} \mathrm{MgCl}_{2}, 10 \mathrm{mM}$ 2-mercaptoethanol, $250 \mathrm{mM}$ sucrose, heparin $(100 \mu \mathrm{g} / \mathrm{ml})$ as an RNAse inhibitor, phenylmethylsulfonyl fluoride $(50 \mu \mathrm{g} / \mathrm{ml})$ as a trypsin-like protease inhibitor, and cycloheximide $(100 \mu \mathrm{g} / \mathrm{ml})$ as an inhibitor of mRNA translocation on cytoplasmic ribosomes, the corcllation weighed tissue sample to volume of this buffer being 1:10. The homogenate obtained was then filtered and run at $18.000 \mathrm{~g}(20 \mathrm{~min})$. A cytoplasmic postmitochondrial fraction was incubated with a $0.5 \%$ Triton X-100 solution (20 min), layered on $0.5 \mathrm{ml}$ $0.5 \mathrm{M}$ sucrose, prepared on the buffer II solution containing no sucrose and centrifugated in a SW 60 Ti rotor (Beckman centrifuge L5-50) (3 h at 49.000 rpm).

Investigation of RNP-particles in a CsCl density gradient. A pellet of cytoplasmic RNP-particles was suspended in the sucrose-free buffer 11 and divided by two; a half of this suspension was a control sample, its second portion was treated by a $15 \mathrm{mM}$ EDTA-Na, solution to cause polyribosome dissociation. Both preparations containing RNP-particles were then fixed (during $24 \mathrm{~h}$ ) in a $4 \%$ formaldehyde solution, all the aggregates formed being removed by pelleting at $10.000 \mathrm{~g}$ (10 min). The soluble material was then centrifuged in a preformed $\mathrm{CsCl}$ density gradient $\left(1.33-1.65 \mathrm{~g} / \mathrm{cm}^{3}\right)\left(12 \mathrm{~h}, 45.000 \mathrm{rpm}, 2^{\circ} \mathrm{C}\right)$ using the same SW $60 \mathrm{Ti}$ rotor.

The fractions of this soluble material were then obtained using a siphon device; each fraction refractive index was determined and compared to densily values of a calibration curve. The fraction optical density was taken in a spectrophotometer at $260 \mathrm{~nm}$. Buoyant density $(\rho)$ of RNP-particles in $\mathrm{CsCl}$ was calculated according to an equation given in 115 ]:

$$
\rho=D \cdot 10.8601-13.4979 ;
$$

$D$ is a refractive index, the values 10.8601 and 13.4979 are experimentally found corrections necessary because of polarizing buffer properties.

Radioactivity of proteins and RNP fractions was determined in a LS 100C scintillation counter ( $\mathrm{Bec}-$ kman») using Millipore AP-15 fibrous glass fillers and scintillator dissolved in tolutene.

Results and Discussion. Whilc claborating our approaches concerning mechanisms of action some synthetic compounds regulating the plant growth we took into account a lot of data suggesting the gene expression changes caused by phytohormones 10 
belong to the principal mechanisms of plant growth and development $[16-18]$ (however, the question concerning regulation expression of concrete genes by each from phyiohormones are not yet correctly answerable). We proposed that the synthetic stimulators of seed germination (similarly to natural plant hormones) increasing drastically the embryonic organism size: and its organ developmen!, canoot mediate their action without some expression changes of genes coding synthesis of structural and functional proteins; the increasing of the plant mass (by cell enlargement anc cell division) being impossible-without intensive protein synthesis swilching on a lot of reactions leating to cell and organ differentiation and specialization.

According to [19], the protein «spectrum» in any cell is to be changed during cell differentiation and specialisation, the prolein synthesis process being a stalye- and organospecific one. We proposed the protein assortment caused by any stimulated embryo growth (in view of accelerated development stages) is to be different from the assortment appeared in normally developed embryos during the same period; itis difference was proposed to be nearly the same as between embryo protein «spectrunt» determined at an car $y$ and at a later postembryonic stages during natural plant development.

The main protein mass in eucaryotic cells is kncwn to be presented by structural proteins and by crizymes of the main metabolic pathway (named also mu ticopied, constitutive, abundant or major protcirs), these compounds being present at all developmontal stages and detected without any difficulty using any one-dimensional gel electrophoresis approach. However, this approach does not permit to find «rare» (so-called minor) stage- and organospe-ific enzymes and regulatory proteins, presented in sonse few copies and «hidden» on «one-dimensional electrophoregrams by major protein bands. So we fractionated a total protein preparation isolated from cmbryonic axes using a two-dimensional polyacrylamide gel electrophoresis (TD-PAC $\dot{ }$ ) protocol.

The stained ge! photographs obtained after our TD-PAGE experiment are present in the Fig. $1(a, b$, $c)$, the total protein preparations having been previously focused following the first one-dimensional separation according to their isoelectric point (pI) in a pH-gradient gel.

Our results demonstrate the absence of any differences in embryonic axis protein preparations of haricol secds after $12 \mathrm{~h}$ of postembryonic development, both normal and LNO-stimulated (Fig. 1, a and b). Simultaneously, the 6-MTU-stimulated hariccl bean germination causes the appearing of a
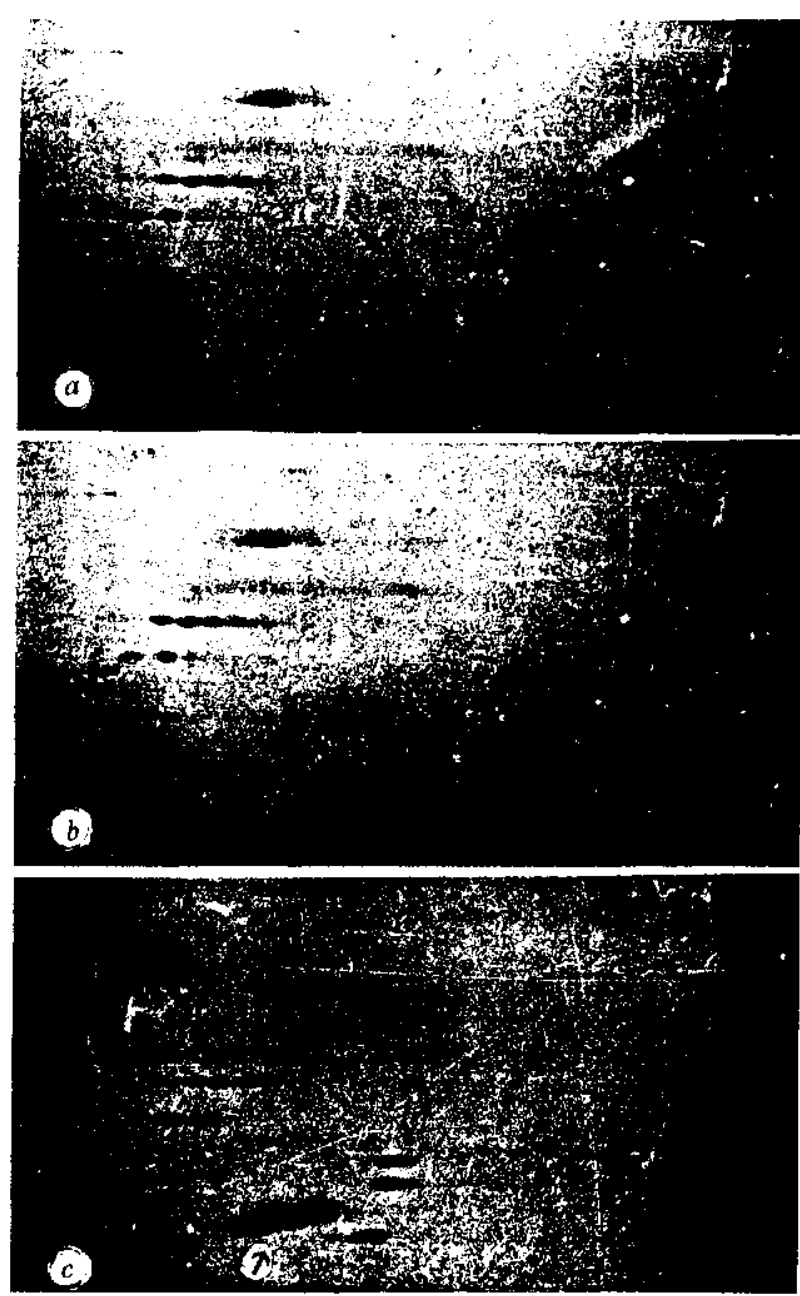

Fig. 1. Two-dimensional polyacrylamide gel electrophoresis of toplasmic proteins isolated from embryonic axis cells in $12 \mathrm{~h}$ post beginning of haricot bean seed germination; the proteins investiga are taken from: $a$... control (non-stimulated) secds; $b \ldots$ IN stimulated seeds; $c-6-M^{\prime} T L-s t i m u l a t e d ~ s e e d s$

«blurred-bordered»spot formed by an about $30 \mathrm{~kJ}$ protein in a zone containing positively charged pr teins (Fig. 1,c). This spot (although of decreas intensity) is also seen in photographs obtained fro TD-PAGE after minimal quantities of tolal prote (4 $\mu \mathrm{g}$ per lane) having been loaded into gel pocket

To determine this protein belonging to major minor ones, we realized in addition an experime with a one-dimensional PAGE approach in the pi sence of the SDS, total proteins of cmbryonic ax after $12 \mathrm{~h}$ of postembryonic development having be loaded on the gel. However, in this experiment failed to detect any separate band of the $30 \mathrm{k}$ ! 
prolein or 10 find any staining band differences between control and 6-MTU-stimulated protein samples. So we concluded this protein to be a minor one, its blurred spot in the TD-PAGE permits to suppose it to be also a short-lived compound. This $30 \mathrm{kDa}$ protein was not detected in embryonic axis preparations in $24 \mathrm{~h}$ after the beginning of non-stimulated germination process, the embryonic axis sizes being the sante as their sizes in 6-MTUstimulated seeds in $12 \mathrm{~h}$ of postembryonic development (no photograph is presented).

The $30 \mathrm{kDa}$ protein detected by the TD-PAGF approach appears only as a result of the 6-MTUstinulated seed germination, no its traces having been found both in control and $\mathrm{LNO}$-stimulated samples; our aim was to gain some data explaining such results. Some physiological consequences of seed treatment by LNO and 6-MTU are similar, the germination periods becoming twice shorter and finishing in 2 days) with both stimulators. However, a lot of intracellular events followed by these substances treatment are to be quite different. There are some facts confirming this point of view. The LNO-treatment stimulates the total cellular protein synthesis proved in our one-dimensional electrophoresis experiment using a $\left.l^{35} \mathrm{~S}\right\}$-methionine labelled in vivo total proteins isolated from embryonic axes and also following a gel fluorography approach [20]. At the same timc, the 6-MTU, according to our data, stiniulates the only unusual $30 \mathrm{kDa}$ protein synthesis.

To explain such a marked difference concerning the effect of two growth stimulating compounds, we suppose they action through different mechanisms influcncing on certain stages of gene expression (1ranscription, formation of synthctically active RNP complexes, mRNA translation, etc.). The LNO was alreddy proved to possess no action specificity on the level of gene expression regulation [20-22] activatiug both transcription and active RNP formation and increasing the synthesis of all the cellular protein is without changing their assortment.

We though1 the appearance of the $30 \mathrm{kDa}$ protein «nou-typical» for a given developmental stage of embryonic axis cells might have been a result of some simulancous changes at the translation level or at any precursor stage of the gene expression regulation (during transcription and/or transcrip maturation leveis). To answer this question, we realized some experiments concerning

1) the comparative investigation of the $L N O$ and 6-MTU effect or the translation process in an in vitro system of protein synthesis using a template of poly (A) RNA as slandard isolated from non-stimulated embryonic axis cells;
2) the study of biological activitics of poly $(\mathrm{A})^{+}$RNA preparations isolated from euntrol embryonic axes as well as from those ones stimulated and non-stimulated by INO and 6-MTU using the same in vitro system of protein syothesis:

3) the evaluation of activity protein-synthesiming apparatus (polyribosomes) in vivo, i. a. proportion of free and incorporated into polyribosomes ("H-uridin. labelling in vivo) of $m R N P$ and $r R N P$ particles in embryo axis haricot bean seeds germinalted withoul any treatment and following LNO and 6-MTU sii. mulation.

In the Fig. $2(a, b)$ the results of sumtuat? cmbryonic axes RNA preparations cusing atgarose git clectrophoresis) obtained with control and 6-MTll. stimulated material; these data demonstrate the $R N A$ preparations to contain non-degraded discrele fras. tions of both high and low molecular masses thriRNA including preRNAs, preRNAs «wasic products» originated due to processing rRNAs, mRNAs and $t R N A s$.

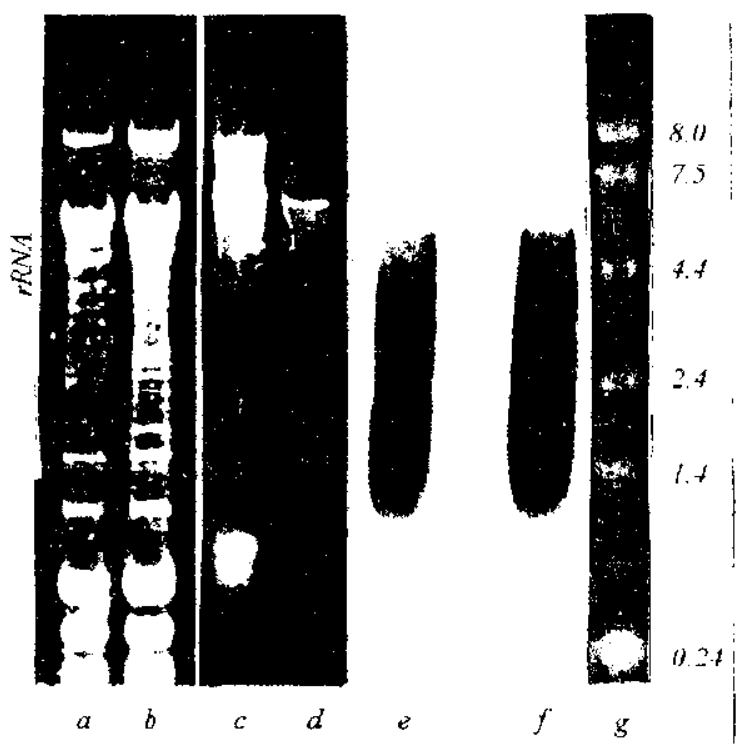

Fig. 2. Agarose gel clectrophoresis of R.VA proparations isolated irm embryonic cell axes in $12 \mathrm{~h}$ post the begiming of harcen beall sedel germination; $u$ and $b-$ total RNA preparations from antrin and 6-M'TL-stimulated seeds, respectively; $c$ and $d-$ pulv $(A, R, A$ and poly (A) ${ }^{+}$RNA preparations, respectively, separated an an aliguld' cellulose column; $c$ and $f$-..- radivatutographs of hytrid mokeules containing $I^{32} \mathrm{Pl}-\mathrm{CDNA}$ and poly(A) RNA fratitions immobilikd au nitrocelluluse filter: poly $(A)^{+} R N A$ and $\left.\right|^{3 !}|P| C D \backslash A$ isolitled from cmbryonic axis cells of non-stimulated (e) and o. M'll stimblated $f f$ haricot bean seeds, respectively; $g$-..- electruphoretic distribution on marker polynuteotide's on a parallel get lan. 
«matture» forms these RNAs of nuclear and cytoplasm, regulatory $R N A$ molecules). The ratios $E_{260} / E_{280}$ and $E_{2 b 0} / E_{230}$ for our preparations were $\geq 2.0$ and $\geq 2.3$, respectively, confirming a good degree of isolated RNA purification being practically free from protein and polysaccharide contaminations. We present also our electrophoregrams of a poly (A) RNA preparation (Fig. 2, c) and of a poly (A) ${ }^{+}$RNA one (Fig. 2, d) demonstrating the rRNA to be pratically absent.

In the Fig. $2(e, f)$ our radioautographs are given obtinined as a result of a Northern blot-hybridization procedure of poly(A) RNA fractions with a $\left[^{32} \mathrm{P}\right]-$ cDNA preparation; our results demonstrate these fraction to contain highly heterogencous poly $(\mathrm{A})^{+}$RNA molecules of different molecular masses (due to differences the lengths of mRNA coding regions as well as of its regulatory ones, apparently); so there is no contradiction to other data $[23]$ concerning the existence of a marked discretion (in the same size ranges) for eucaryotic mRNAs (from 8.0 up to 0.24 kbs); a series of spots fused along gel lanes can be seen on our photographs because of radioactive track autographs being overlapped on the $X$-ray film due to labelled highly heterogeneous hybrid mRNA-cDNA molecules localized on the filter too near from each oth.r. An clccirophoregram presenting marker polynucleotides is also shown (see Fig. 2, g). So it is clear the poly $(A)^{+}$RNA preparations studied here to be non-degraded ones and to keep their high molecular cour ponents.

However, the principal nativity criterion for any poly (A) RNA molecules is their messenger activity directing the polypepticle synthesis process in in vitro (cell-free systems); the evaluation of RNA messenger activity was a principal moment in our investigation.

In the Fig. $3(a, b)$ the kinetics of $\left[{ }^{35} \mathrm{~S}\right]-$ methionine incorporation into the TCA-insoluble ma terial is presented; these data were obtained in a well-known wheat embryo cell-free system using a template poly (A) RNA as standard isolated from emtryonic axes of non-stimulated haricot bean seeds. Our control data concerning TCA-insoluble fraction radioactivity were obtained with the same in vitro syslem containing no growth activator (see Fig. $3, a$ ). We evaluated also the effect of the LNO and 6-MTU added to the incubated mixture (Fig. $3, b$ and $c$, respectively). We would like first of all to note the label incorporation increase during incubation in all the experiment materials (including also control ones) suggesting the nativity of poly $(A)^{+}$RNA preparations used. Our second finding is that the 6-MTU inhibits slightly the level of protein label incorporation during all the incubation period comparing to the control

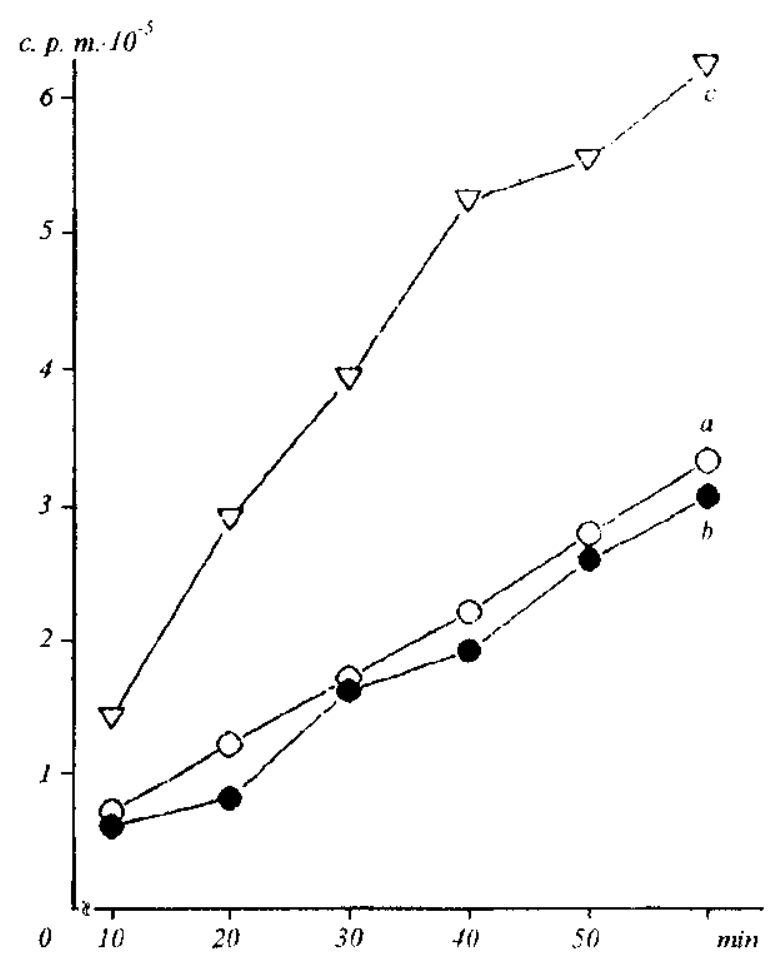

Fig. 3. Kinetics of $\left[^{35} \mathrm{~S}\right]-$ methionine incorporation into the TCAinsoluble material in a wheat embryo in vitro system with using as template poly $(\mathrm{A})^{+} \mathrm{RNA}$ : $a$ - a control sample (no growth stimulators were used); $b$ and $c-$ label incorporation into peptides in the presence of the 6-MTU and LNO, respectively

incorporation level. On the contrary, the LNO stimulates the poly (A) RNA directed polypeptide synthesis in our in vitro system, the synthesis level becoming almost twice higher.

Thus our results prove directly that the LNO activates the translation processes as well as the transcription one $[20,21]$; while the 6 -MTU have no regulatory effect on this crucial stage of gene expression.

So it became of great interest to compare some functional properties of embryonic axes poly $(\mathrm{A})^{+} \mathrm{RNA}$ preparations isolated from 6-MTU-stimulated and control haricot bean seeds. In the Fig. $4(a, b)$ there are fluorograms demonstrating the PAGE distribution of polypeptide fractions. They had been previously labelled by $\left[{ }^{35} \mathrm{~S}\right]$-methionine in cell-free system from rabbit reticulocytes using of poly (A) ${ }^{+}$RNA as template RNAs isolated from embryonic axes of haricot been 


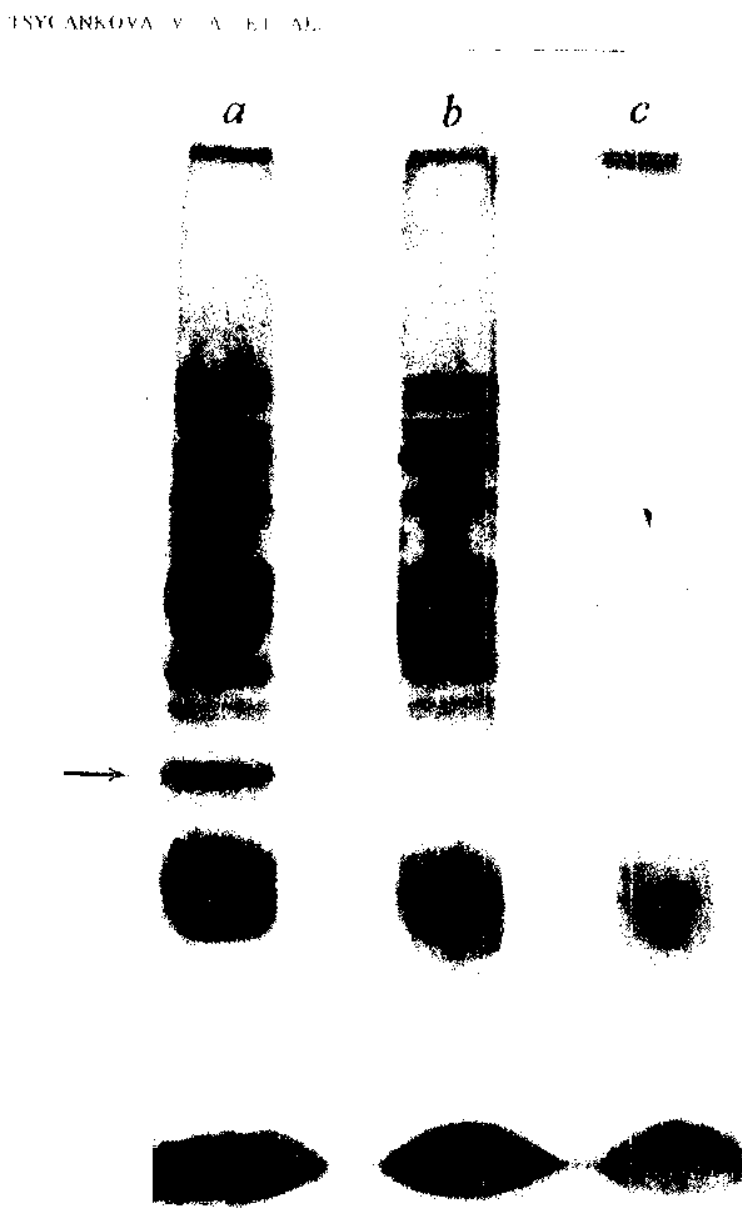

Fig. 4. Fluorographic analysis of electrophoretic polypeptide uspecurumo in the course of poly $(A)^{+}$RNA-directed in vitro synthesis (atbit reticulacyle cell-free system): polypeptide synthesis in the presence of poly $(A)$ RVA preparations from 6-MTL stimulated $(a)$ and non stimulated (b) embryonic dxis cells, respectively; $c-$ label incorporalion in vitro symasized peptides in the absence of atry arded polve $)^{\top}$ RIA preparation (control sample)

sects following germination stimulated and nonstimulated by 6-MrU. The in vitro synthesized polypeptide frations are very similar with both RNA preparations used with the only exception: an additional polypeptide was detected in a gel zone of low molecular weight proteins while analyzing the labelled material from the incubation mixture containing the poly(A) RNA preparation isolated from 6-MTU-stimulated embryonic axes. Our data do not irreprocechably prove this additional peptide to be identical to the one detected in our previous in vivo studies. However, we have a fact of some 6-MTU-induced changes of an active poly $(A)^{+} R N A$ pool, i. C. of the 6-MTU participation in the regulatory transcription mechanisms.
However, contrary to in vitro experincents, ans regulative events having taken plate at the transcription level in vivo cannot be realized at translation level because of several following cir cumstances: mRNA molecules exist and function in any plant cell as informosomes, i. a mRNP-particles [24], no «naked» RNA is there present: at any stage of plant development there are bolh a reserved poot of functionally inactive mRNP being activaled al following stages and a pool of "working» $m \mathrm{R} N$ ? $^{*}$ taking part in the translation process.

The isolation of any poly (A) RNA preparation using phenol deproteinization of mRNP abolishes these mentioned above differences of mRNA pools. both types of them becoming equally able to bu translated. So we needed to answer the question concerning the correlation between the appearance of the $30 \mathrm{kDa}$ minor protein in vivo and the changes at the 1ranslation level due to $1 \mathrm{he}$ 6-M $\mathrm{MU}$-induced regulatory changes of transeription process. So we studied the correlation of active lincorporated inter polyribosome complexes) and frec, inaclive in protein synthesis mRNPs in embryonic axis cells following stimulated and non-stimulated haricol bean seed germination.

The data concerning the CxCl gradient frat tionation of formaldehyde-fixcd RNP-particles isolated from stimulated and control seeds are given in the Fig. $5(a-d)$. In both calses the obtained rat dioactive profiles of RNP-particles in the CsCl gratdient are presented by two radioactivity maximal. their densities being 1.39 and $1.42 \mathrm{~g} / \mathrm{cm}^{3}$, respectively (small «peaks» of free informosomes), and two large peaks with their densities $1.52 \mathrm{~g} / \mathrm{cm}^{*}$ (for the $0^{-}$ MTU-stimulated material) and $1.54 \mathrm{~g} / \mathrm{cm}^{4}$ (for the control sample), respectively, presunting de non. synthesized mRNP and rRNP-particles incorporated into polyribosomes. While ELTA trating of RN? preparations only a small part of radioalivity (fol lowing pulse RNP labelling during $1 \mathrm{~h}$ ) rematists in the region of ribosome subparticles localization. the main radioactive pool in both conlrol and ixperimemal samples being transported to the region of fret informosomes; its peak in control is localizcd it $1.45 \mathrm{~g} / \mathrm{cm}^{3}$; however, the pulse-labelled RNP's of stimulated material form two peaks, the lesser on being concentrated in a region of the busyant densily $1.39 \mathrm{~g} / \mathrm{cm}^{3}$, the last main labells materiat being found in a narrow de nowe appcared peak al $1.46 \mathrm{~g} / \mathrm{cm}^{3}$.

So we note a clear correlation belween the 6-MTU-induced changes of transcription process a: well as of poly $(A)^{2}$ RNA messenger activity (inducing: the additional protein synthesis) influching the 

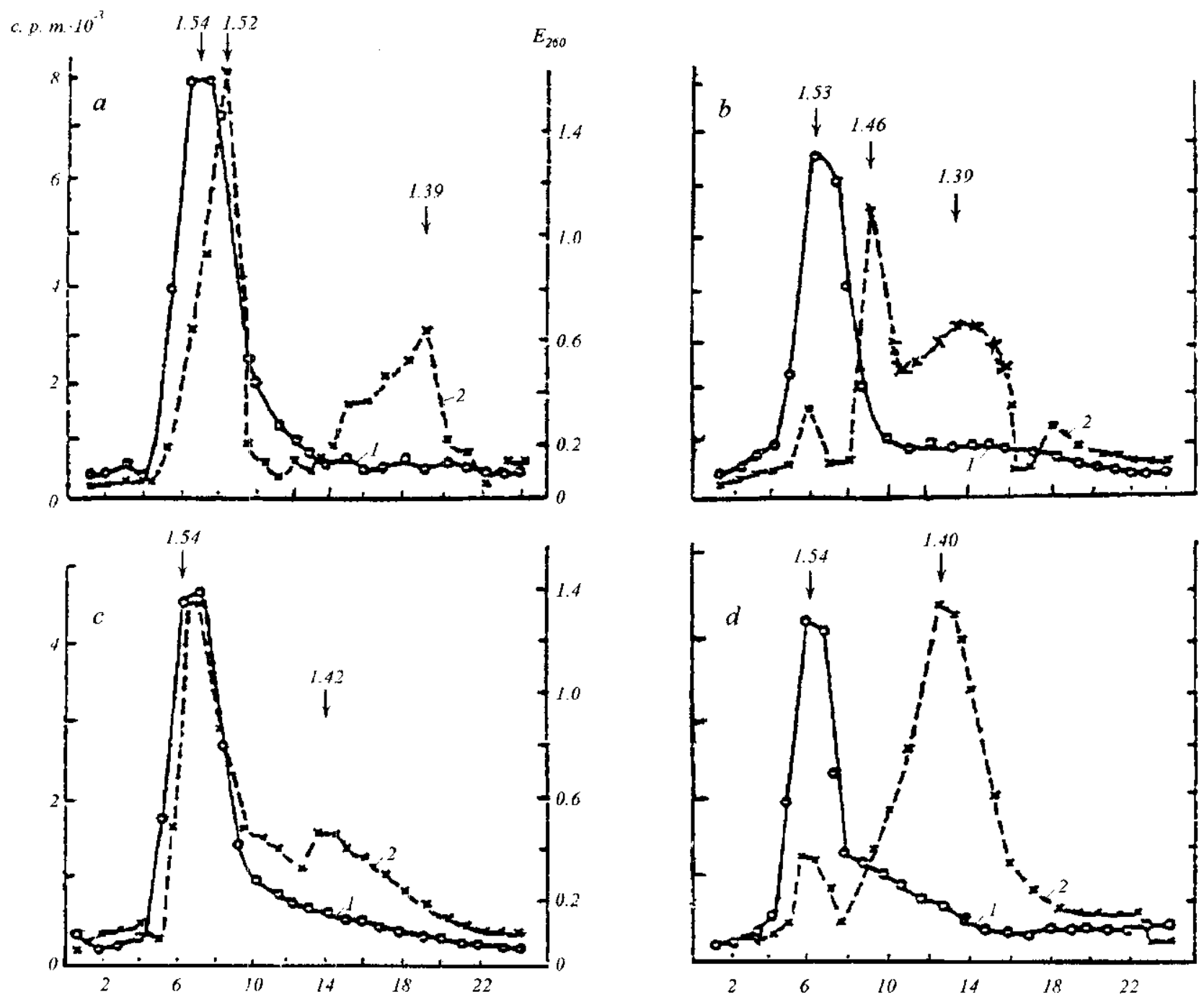

Fig. 5. Fractionation of RNP-particles in a CsCl density gradient: $a$ and $b-$ RNP-particle preparations from ernbryonic axes of MTL-stimulated seeds, untreated by HD'TA and treated ones, respectively; $c$ and $d$ - RNP-particle preparations from embryonic axes of non-stimulated seeds, untreated by EDTA and treated ones, respectively

qualitative changes of acting mRNPs (included into polyribosomes) and the appearance of the minor protein in embryonic axis cells in vivo; however, to prove the identity of protein molecules produced in. vitro and in vivo, immunological approaches are necessary as well as the study of in vitro obtained protein fractions whose synthesis is directed by mRNAs isolated from polyribosomes.
It is also evident the changes being realized by synthetic plant growth activators on the gene expression level and triggering most probably the acceleration of plant growth and development are to be a result of natural developmental process modifications due to the activator effect.

Today two tightly interconnected forms of plant growth and regulation are known - genetic control 
TSYGANKGWA $V$ A ET AJ.

and phytohormonal regulation; the results of their interaction may be summarized as follows:

(i) the plant genome codes the synthesis of cellular constitutive (i. c. common for all the development stages) structural and functional compounds as well as of stage- and organospecific ones to assure all the successive cvents of cell differentiation and specialization accompanying the formation of new tissues and organs;

(ii) phytohormones being derivative of gene functions (through a series of protein-enzyme molecules) as well as some other factors according to the feed-back rcgulation realize the re-programming of the cell genome by switching on and off conditionally «early», «middle», and «latc» genes [25] controlling the formation of stage-specific cell homeostasis and, besides, participating in the regulation of «peripheral» intracellular metabolic processes.

The question to be now answered is how the synthetic plant growth regulators are wedged (inscribed) in such a well-coordinated multi-step regulation hierarchy?

This problem was earlier discussed in delail in our previous paper [1]; we propose that the synthetic compounds with their unusual structures having been never found in any plant cell are hardly able to realize their effect through the cell receptor system specific for a lot of natural compounds. It is more probably they mediate their effect by changing the active endogenic phytohormonal pool. An alternative explanation may also be proposed -- a non-specific effect of growth regulatiors due to, apparently, of their higher binding (affinity) with cellular effector systems (being their specific «binding sites» or «targets») realized more quickly comparing to natural phytohormones, the last ones being forced out from their own receptors. The combined action of growth regulators (observed in our experiments with the LNO) cannot be also ruled out; it may include a phytohormone-mediated effect at the transcription level and a direct regulator effect at the translation one (in addition to mentioned above the taking down of inhibitory action ABA by growth activators is possible).

Discussing a possible $30 \mathrm{kD}$ a protein function one may suppose that the plants possess some genes coding some «obscure» protein products being normally absent; the promoters of these «silent», «cryptic», «hidden» genes («archaeological signs») are able |26 \}, however, to be switched on by certain stress factors; in our experiment the 6-MTU was shown to be such a factor. We suppose that the $30 \mathrm{kDa}$ protein is one from enzymes transforming the «unsuitable» («strange») for cells 6-MTU structure into a natural substance possessing a phytohormone activity; this phytohormone is able to accolerate drastically the plant cell growth by enlargement because in early postembryogenesis embryonic axis growth due to enlargement of hypocotyl. The «ephemeral» $30 \mathrm{kDa}$ protein appears and disappears very quickly, according to entering into cells and disappearance from cells the 6-MTU. The data of work $[27 \mid$ witness in behalf of such possibility. Authors discovered the timing changes in enzymes synthesis in elicitortreated cell suspension cultures of Parsley.

It should be noted that this $30 \mathrm{kDa}$ polypeptide is highly similar to polypeptide, forming the base of hydroxyproline-rich glycoprotein extensin the molecular mass of glycoprotein is $86 \mathrm{kDa}$, while its polypeptide without carbohydrate part forms precisely $30 \mathrm{kDa}$ ) $[28-30]$, which is the major protein components of the cell wall of dicotyledon plants. Extensin comprises 5-10\% from all proteins of cell wall and executes plural functions for cell. According with these works $30 \mathrm{kDa}$ polypeptide is positively charged ( $\mathrm{pI}$ of 9.9) and soluble in water medium precursor of extensin. This polypeptide is synthesised and glycosylated by posttranslational modifications in cytoplasm and then integrated into the cell wall space. The expression one of the extensin gene family (SbHRGP3) increases with seedling ma1uration, and its expression is reiatively high in the mature regions of the hypocotyl and in the root of soybean seedlings (it is possibly that the intensification of expression some from extensin genes under the of 6-MTU stimulated haricot bean seed germination is noted).

The finale step of our work consisted of experiments concerning the effects of the LNO and 6-MTU (possessing quite different mechanisms) on the following haricot bean ontogenesis. So the plants originated from germinated seeds (with or without growth stimulators) were cultivated further on the minimal nutrient media. It was shown the 6-MTUstimulation of seed germination to cause a significant plant development acceleration comparing to control plant ontogenesis duration (it is about 40 days in laboratory conditions); a plant originated from al 6-MTU-stimulated seed is able to complete its development in 25 days having passed all the ontogenesis steps including also flowering, ovary and even pod formation, its root network being also well developed (sec Fig. 6, $a, b$ ). At the same lime the LNO-induced seed germination leads to the plant growth deformations - accelerated growth of stems carrying underdeveloped foliage, no reproductive organs having been formed (not shown).

It is also noteworthy the similar effect of vegetative organs predominance is usually seen in plants 

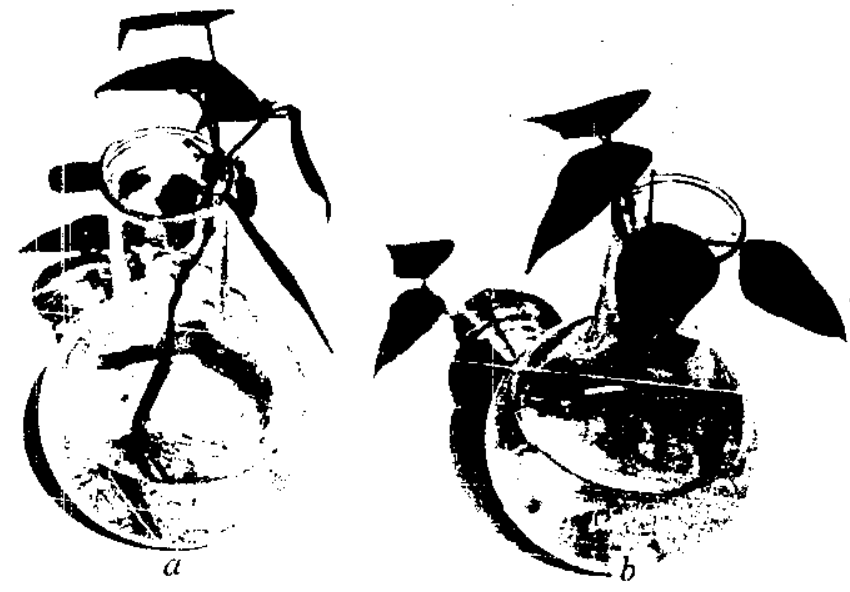

lïg. 6. Plants grown from haricot bean seeds germinated without any stimulation $(a)$ and following the 6-MTU directed stimulation $(b)$

growing on soils containing superfluous organic fertilizers; the abundance of organic compounds is known to cause the nitrogen metabolism activation in plant cells, this process being somewhat analogous to the LNO-induced total protein synthesis.

It should be also taken into account the LNOinduced increased total protein synthesis and the 6-MTU-induced accelerated minor protein synthesis (1hise phenomena are somewhat similar to synthesis with protective functions of heat and cold shock proleins in plants to response on critical or extremely hign or low temperatures, respectively, for example \{31 j) may be genetic «markers» determining the following plant development (vegetative organs predominance or complete although shortened ontogenesis) already at the carly postembryogenesis stage.

Concluding this paper we would like to note the selcctive 6-MTU-induced high level synthesis of the only minor protcin suggests the gene coding this protein to belong to a family of unique genomic DNA sequences, its function being controlled by a strong promoter. The cloning of this markedly inducible promoter is to be perspective in the field of plant genetic enginecring, namely, for recombinant gene constructions whose expression in transgenic plants is to be induced by $6-\mathrm{MTU}$.

Acknowledgement. Authors thank professor V. M. Karsan for letting cnzyme reversc transcriptase. в. А. Цисанкояа, в. М. Заєць, л. О. Галкіна,

Л. П. Приказникова, Я. Б. Блюм

Поява незвидайного мінорного білка в клітинах зародкової осі при стимуляції проростанн насіння квасолі 6-метилтіоурацилом

\section{Резюме}

За допомогок двомірносо електрофорезу білків у поліккриламідному гелі виявлено незвичайний мінорнии білок з молекулярною масою $\approx 30 \mathrm{kДа} \mathrm{у} \mathrm{клітинах} \mathrm{заробкової} \mathrm{осі} \mathrm{при} \mathrm{стниу}$ ляції проростання насіння квасолі (Phaseolus vulgaris $L$.) 6 -ме?тилтіоурацилом. ПТову цього білка не зафіксовино в нормі та при проростанні, стимульованому N-оксиоом лутидина. ('ин мез додаткового низькомолекулярного бізка спостерісався макож у безклітинній системі з ретикупоцитів кроля на манриці полі( A) РІІК, одержалій з клітин зародкоай осі кваспле вого насіння, обробленого б-метилтіоурицилом. У тои же час у безклітинній системі з проростків пиениці ири викори. станні "спандартного" препарату полі (A) РНК показано, ио N-оксид лутидина різко стимулюе синтез поліпетmuдіs, а метилтіоурацил прямо не вптивас иа процес трансляиї.

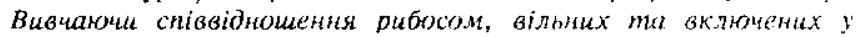
nолірибосоми in vivo, за допомосою рракціонуваннs PHН-4астонок у преформованому градіснті густин СsСl, остановиено nрисутність dotamкового піка $\left(1,46 \mathrm{l} / \mathrm{cm}^{3}\right)$ y ppakuї noлірибосом 3 зародкових осей насінил, обробленого а-метинпіоурацилом. Така стимуляція сутпксво скорочуе період онто-

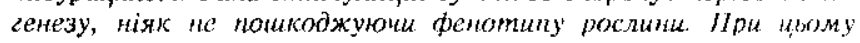
обробка пророцуваного насіння $N$-оксидом тутидина призво. duть dо деформозаного прискореного розвитку весемативних органів без розиитку орсанів розмноження рослини обговорюеться природа білка 30 кДа $і$ взаємозалежніспи між з.мінами в експресї генія, ио викликані ростовими смимуняторами у клітинах зародкової осі під тас ранньке nосмембріогенезу, ма наступними різнонаправленими проиесами роспу

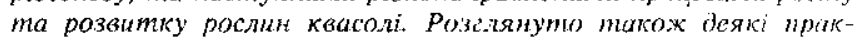
тичні папрямки застосування ростових стимуляторів, пов'язані з результатами проведених експериментік.

B. А. Цизанкова, в. Н. Заец, Л. А. Галкина,

Л. П. Приказчикова, Я. Б. Блим

ГІоявление в клетках зародышевой оси необычного белка при стнмуляции прорастания семян фасоли 6-метилтиоурацинюм

Резюме

С помощью дзухмерного электрофореза белков в потиакрила миднам ееле показано появление в кленках зародыневой оси при стимулируемом 6-мотилтиоурацилом прорастании семял

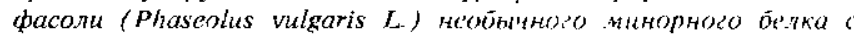
молекулярной массой около 30 кLа. Эмот белок не обнаружи-

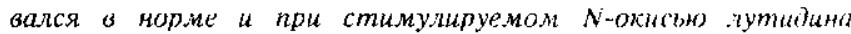
прораспании семян растений. Синтез дополнштельного низкомолекулярного белка отменен и в бескльпоной састеме бел кового синтеза из ретикулоцитов кролика на натрице по

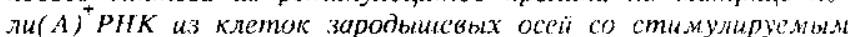
6-метилтиоурацилом прораспанием семяи дасоли. $B$ mo же время с помощью бесклепочнои кисте.мы белководо синтеза из проростков пиеницы с использованием а катеспве матрины

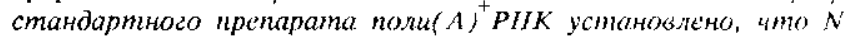
окись путидина резко стимулирует синтез полипептиооя, а 6-метилтиоурацил не оказывает прямого влияния на процес mрансляции. Изуиение соотноиения свободных и включенных в полирибосомы информосом іп vivo методом фракционирования РНП-иастиц в преформированном градиенте номности (.sCl 
втяянио присупствие во фракции полирибосом из зародыиевых ocet при стимулируемом 6-метилтиоурацилом прорастании ссмин dополнительного пика активных в белковом синтезе информосом с плавучеи плотностью $1,46 \mathrm{z} / \mathrm{cm}^{3}$. Показано, чmс стиму.ляция прораспания семsн фасоли 6-метилтиоура «илім приводит к суцестьзеному сокрацению срокоз онтоге"є:зе: растения фасоли бе. каких-либо наруиений фенотипа распения, а стимуляция $\mathrm{N}$-окисью лутидина - $\kappa$ деформировоніому ускоренному развития весетативных органов без разиитая репродуктивных орсанов растения. Обсуждается природа белка 30 кда и связь межনу различиями в изменении

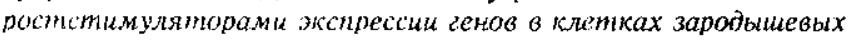
осеі в раннем постамбриосенезе и последуюиими разнонаправnениьми процессами роста и развития растений фасоли, а пак же некопорые практические аспекты, оытекакщие из slitoco.

\section{RFFIERENCFS}

1. Tsygankova $V$. A, Blume Ya. B. Screening and peculiarity of the biological action of syuthetic plant grow/h regulators // Biopolymers and Cell,-..1997.-13, N 6.-P. 484-492 (in Engl.).

2. Martyn G. I., Musutenko $L$. I., Sytnyk K. M. Embryonic axis morphology on the early stages of harico: bean seed germination // Proc. Acad. Sci. Ukr., ser. B. - 1976. - N 11.P. $1039-1042$ (in Ukr.).

3. Murtyn G. I., Nesierova A. N., Berestetski V. O. Morphological and physiological properties of haricol bean embryonic development // Lkr. Bot. J.-1980.-37, N 4.-P. 11-14 (in $\mathrm{Ukr}$.

4. Misatenke L. J., Galkin A. P., Pushkariov V. M., Sytnyk K. $M$. Study of early stages of genome expression in primary embryonic axis organs during haricot bean seed maturation and germination // Plant Genome: Structure and Expression.Lfa: Publ. Bashkirsky Depart. Acad. of Sci. USSR, 1983.P. i 54--161 (in Rus.).

5. O Farrell $P$. H. High resolution two-dimensional electrophoresis of proteins // J. Biol. Chem. $-1975,-250$, N $10 .-$ P. $4007-4021$.

6. Laemmli $U . K$. Cleavage of structural proteins during the assembly of the head of bacteriophage T4// Nature. - 1970.227. - P. 680-685.

7 Aviv H. Leder $P$. Purification of biologically active messenger RNA by chromatography on oligothymidylic acid-cellulose // Proc. Nat. Acad. Sci. USA.-1972,-69, N 6.-P. 14081412.

8 Locker $J$. Analytical and preparative elcctrophoresis of RNA in agarose-urea // Anaty1. Biochem.-1979.-98, N 2.P. $358-367$.

9. Maniatis T., Fritsch $F$. F., Sambrook J. Molecular cloning: A laboratory manual. - New York: Cold Spring Harbor Lab., 1982.-.. 3. 345-349

10. Buell G. N., Wickens M. P., Payvar F., Schimke R. T, Synthesis of full length cDNA from partially purificd oviduct mR.VA // J. Biol, Chem,--1978.--253, N 7.--P. 2472-2482.

1) Denhardt $D$. $T$. A membrane-filter techniquc for detection of complementary DNA // Biochem. and Biophys. Res. Commuts. $-1966 .-23 .-$ I'. $^{2} 641-646$.

12. Murcus A., Ejron D., Week D. P. The wheat embryo cell free system // Meth. Enzymol-1974-30.-P. 749-754.

13 Bonner $W . M$. Laskey R. A. A film detection method for tritium-labelled proteins and nucicic acids in polyacrylamide geis // Fur. J. Biochem.-1974.--46, N 1.-P. 83-88.

14 Osterman $L$. A. Methods of protein and nucleic acid research.-Moscow: Nauka, 1981.-250 p. (in Rus.)

15. Parchomenko N. I., Didenko L. F., Maxymenko L. A.
Physico-chemical properties of prosomes from Datura sirammonium $L$ leaves infected by the potato $X$ virus // Bio. polymers and Cell. $-1996 .-12, \mathrm{~N}$ 6.-P. 102--I II (in Rus.)

16. Gamborg K. Z., Kulaeva O. N., Muromtsev G. S. et al. Plan growth regulators. - Moscow: Kolos, $1979 .-246$ p. (in Rus.).

17. Polievoi V. V. Phytohormones-Leningrad: Publ. Leningrad sky Univ, 1982.-249 p. (in Rus.).

18. Parthier $B$. Hormone-induced alterations in plant gene expression // Biochem. Physiol. Pflanzen. - 1989. -185.-P. 289 . 314.

19. Dure L., Greenway S. C., Galau G. A. Developmental biochemistry of cottonseed embryogenesis and germination: changing messenger ribonucleic acid populations as show by in vitro and in vivo protein synthesis // Biochemistry. $-1981,-20$, N 14.-P. 4162-4168.

20. Galkina L. A., Zayets V. N., Prudiev D. M. ef al. Fraction composition of de novo synthesized embryonic axis proteins following haricot beans seed germination activated by «ivin yan" // Physiol. and Biochem. of Cullivated Tlants. Acad. Sci Ukr.-1989.-21, N4.-P. 346-351 (in Rus.).

21. Klikhar V. P., Pushkariov V. M., Galkina L. A. Ivin yan induced stimulation of cytoplasmic riboulucleoproteinic particlo biosynthesis in embryonic axis cells from germinating haricon bean seeds // Proc. Acad. Sci. L'kr, ser. B...1987.-.N 7.P. $76-78$ (in Rus.).

22. Kukhar V. P., Galkina I. A., Prikazchikova I. P. Chemica regulators of gene activity in plant cells // Adv. school on the «Genes transfer and regulation of their expression in cuka. ryotes» organized through the scientific cooperation belween the National Academy of Sciences of Lkraine (Likraine, Kiev) and the $\boldsymbol{P}$. Sabatier University (krance, Toulousc)--Kiyv, 1993.-P. 26-28 (in Engl.)

23. Wallace $D$. $M$. Precipitation of nucleic acids $/ /$ Meth. En zymol. - 1987.-152.-P. $41-48$

24. Aitkhozhin M. A., Iskakov B. K. l'lan! informosomes.-Alma Ata: Nauka, 1982.-P. 182 (in Rus.)

25. Galau G. A., Dure I. Developmental biochemistry of cottonseed embryogenesis and germination: changing messenger ribonucleic acid populations as shown by reciprocal heterologous complementary deoxyribonucleic acid-messenger ribonucleic acid hybridization $/ /$ Biochemistry,--1981,-20, iv 14.P. $4169-4178$.

26. Grgzelyak N. V., Galkin A. P., Gening L. V. et al. Chloroplas «cryptic* promoter can be activated upon their transfer to plant nuclear genome // Biopolymers and Ccll._-1996..-12, N 6.P. 87-93 (in Fingl.)

27. Bollmann J., Hahlbrock $K$. Timing of changes in proteit synthesis pattern in elicitor-treated cell suspension cultures of Parsicy (Petroselinum crispum) // $Z$. Naturforch...1990.— 45, N 9-10.-P. $1011-1020$.

28. Chen J., Varner J. E. An extracellular matrix protein in planis: characterization of a genomic clote for carrot extensis $/ /$ EMBO J. - 1985. -4, N 9.-P. 2145--2151

29. Evans I. M., Gatehouse L. N., Yarwood J. N. et al. The extensin gene family in oilseed rape (Brassica napus L.) characterization of sequences of representative members of the family // Mol. and Gen. Gene1.-1990-223.-P. 273-287.

30. Ahn J. H., Choi $Y_{\text {, }}$ Kwon $Y . M$. et al. A novel extensin gent encoding a hydroxyproline -rich glycoprotein requires sucrose: for its wound-inducible expression in transgenic plants // The Plant Cell. -1996.-8.-P. 1 477-1490.

31. Meyer M., Chartier $Y$. Long-lived and short-lived heat-shock proteins in Tobacco mesophyll protoplasts // I'lant I'hysiol.-[983. - 72, -P. $26-32$.

Received 24.02 .98 